\title{
Paying the Penalty? The High Price of Penalty Rates in Australian Restaurants
}

\author{
Phil Lewis ${ }^{1}$
}

\section{Abstract}

As a result of decisions by numerous state and federal commissions and tribunals, most recently the Fair Work Commission, penalty rates have become an important influence on the labour market in Australia. The paper investigates how relevant are the myriad penalty rates to today's social mores and the modern service-based economy. What are the consequences of penalty rates for employment, productivity, profitability and consumer welfare? What would be the impact of their removal? A number of data sources are analysed in the context of the economics of labour markets to answer these questions. The restaurant, café and catering industry is used as a specific example to illustrate the effects of penalty rates.

\section{Introduction}

Penalty rates by their very name imply that businesses must pay a penalty for imposing conditions which are said to disadvantage employees. The notion of a 'penalty' rate has its origin in a labour market quite different from that of much of the Australian labour market today. The Australian economy used to be characterised by mostly males working full-time in industrial jobs. There was little part-time or casual work. Working married women and jobs with flexible hours were rare (Norris et al. 2004). Most retail outlets shut at midday on Saturday and reopened on Monday. The weekends were, for many, the only time available for socialising, recreation, participating in sport and worship.

The Australian economy has undergone significant structural change over the past three decades, the pace of which accelerated in the late 1980s and 1990s. While policy has changed, industries have also embraced new technologies and have become increasingly involved in the global economy. There have been significant changes in labour demand (Lewis et al. 2010). The demand

1 University of Canberra; Phil.Lewis@canberra.edu.au. 
for full-time workers, particularly males, has not kept pace with supply. The growth in part-time work has been an important source of jobs growth. There has been a substitution of female workers, particularly part-time, for full-time male workers. For certain groups, the changes in demand have been particularly noticeable. For instance, a full-time job for anyone 15-20 years old is now an exception rather than the rule and if you are a youth in a part-time job there is an over 80 per cent chance you will be a student (Lewis and McLean 1998). Another major feature of the changing Australian labour market is growth in casual employment. The growth of casual work was an important phenomenon in the 1980s and 1990s and the proportion of all employees that is casual reached over 20 per cent by 2010 (ABS 2010).

Much of the changing composition of employment can be attributed to a changing industry mix. In 1975 the 'soft' services (such as health, finance, retail, education, restaurants, and so on) accounted for just over 50 per cent of all jobs, but by 2013 the sector accounted for more than 70 per cent of all jobs (ABS 2012a). By contrast, manufacturing's share of total employment almost halved over the same period to about 10 per cent in 2013. There were also reductions in the relative shares of jobs in the 'industrial' services (such as construction, communications, electricity, gas and water). With respect to the distribution of employment by occupation the picture that emerges when combined with the industry distribution is that a 'typical' Australian worker today is a 'white-collar' employee in the service sector (Lewis 2008). It may be thought that for a modern service-based economy, such as Australia, imposing higher wages (penalty rates) when the demand for services is often greatest is something of an anomaly.

In this paper it is argued that penalty rates have significant negative effects on the economy. An industry particularly affected by penalty rates, namely the cafe, restaurant and catering industry, is used as an example to illustrate these effects.

\section{Are penalty rates relevant to modern Australian society?}

Penalty rates have their origins in social mores of the past. The thinking behind penalty rates is encapsulated in the original decisions of the Commonwealth Court of Conciliation and Arbitration (CCCA). For instance: 
... the (extra rate for Sunday work) is given because of the grievance of losing Sunday itself - the day for family and social and religious reunion, the day on which one's friends are free, the day that is the most valuable for rest and amenity under our social habits ...

The norm of work should be six week days and Sundays free, the departure from the norm should be two time-and-a half rates, which is equivalent to one double rate. (CCCA 1919)

and:

Saturday, it is said, is the great day of recreation, while Sunday is the day of religious observance and family reunion. Saturday is the day on which competitive sports and various forms of organised social activities and public entertainment are held, as well as being the day which by common usage has come to be set aside for individual recreation in outdoor activity. (CCCA 1947)

For some, very much the same logic applies today to a very different economy. For instance, this view is encapsulated in this speech (D'Amore 2005) in the New South Wales parliament:

Shift loadings and penalty rates for work in ordinary time on weekends and work outside the normal span of hours are intended to compensate for the inconvenience associated with working unsociable hours. Work after 5.30p.m. is generally regarded as being in unsociable hours, and has a negative impact on both personal and family wellbeing. With a higher female participation in the work force, the pressures on family interaction are now greater. For individuals this pressure has increased with more work being performed during unsociable hours.

and:

Employees are less inclined to work on Saturdays and Sundays because they are dominant days for sport, leisure, community activities and religious celebrations. Time off during the week does not compensate for time lost on Saturdays and Sundays. This is the reason workplace arrangements have always recognised and endorsed penalty rates in the form of higher hourly payments for these days. Working unsociable hours interferes with family and personal commitments and has a negative impact on family relations, family and individual wellbeing.

The ABS produces estimates of individuals' and households' time use, including time spent on leisure activities. The ABS (2008a) definition of sport and outdoor activity includes organised and informal sport, exercise, walking, fishing, hiking 
and holiday travel and driving for pleasure. According to the ABS (2008) (Table 1 below), the amount of time spent on sport and outdoor activity (25 minutes per day) was the second-most popular activity for men in 2006.

However, audio/visual media (154 minutes per day) far exceeds time spent on sport. For women, time spent on sport and outdoor activity (17 minutes per day), again was eclipsed by time spent on audio/visual media (122 minutes per day); talking and correspondence (36 minutes per day); reading (25 minutes per day) and other free time (18 minutes per day).

Table 1: Average time spent on leisure activities (2006, minutes per day)

\begin{tabular}{lllll}
\hline & Males & & Females & \\
& Weekday & Weekend & Weekday & Weekend \\
& & & & \\
\hline Socialising & 6 & 20 & 7 & 19 \\
Visiting entertainment venues (a) & 2 & 8 & 4 & 8 \\
Attendance at sports event & $* 1$ & 6 & - & 4 \\
Religious activities (b) & $* 2$ & 8 & 4 & 10 \\
Community participation & 8 & 7 & 11 & 9 \\
Associated travel & 7 & 22 & 9 & 21 \\
Social and community interaction (c) & 27 & 71 & 35 & 73 \\
Sport and outdoor activity & 20 & 37 & 16 & 21 \\
Games, hobbies, arts, crafts & 13 & 18 & 11 & 15 \\
Reading & 19 & 25 & 23 & 29 \\
Audio/visual media & 144 & 181 & 117 & 134 \\
Other free time & 20 & 29 & 16 & 24 \\
Talking and correspondence (d) & 21 & 31 & 34 & 43 \\
Associated travel & 5 & 10 & 4 & 6 \\
Recreation and Leisure (c) & 243 & 332 & 223 & 273 \\
Total free time & 270 & 403 & 259 & 346 \\
\hline
\end{tabular}

*estimate has a relative standard error of 25 per cent to 50 per cent and should be used with caution.

- nil or rounded to zero (including null cells).
(a) includes cultural venues.
(b) includes ritual ceremonies.
(c) includes additional activities not separately included.
(d) includes talking on phone or reading/writing own correspondence.

Source: Australian Bureau of Statistics (2008a), Time Use on Recreation and Leisure Activities, Australia, Cat No 4173.0. 
As Table 1 shows, the average amount of time that people spent on recreation and leisure activities increases on the weekend compared with weekdays, with men spending more time (332 minutes a day) on the weekend on these activities than women (273 minutes a day).

For men the amount of time spent on sport and outdoor activity increases by only 17 minutes per day on the weekend and for women by only five minutes per day compared with time spent during the week. Men spend more time on the weekend on sport and outdoor activity than women (37 minutes compared with 21 minutes).

Religious activity is found to be a relatively minor activity with respect to time use. Just as for weekdays, by far the greatest expenditure on free time is in audio/visual media (45 per cent for men and 39 per cent for women). The total amount of free time in the week is 33 per cent lower on the weekdays for men and 25 per cent for women.

Therefore, even under this extremely broad category of sport and outdoor activity, the time spent, even on weekends, is not large and pales into comparison with other activities. Clearly, for most, working on weekends would not significantly impose on their time spent on sport and outdoor activities.

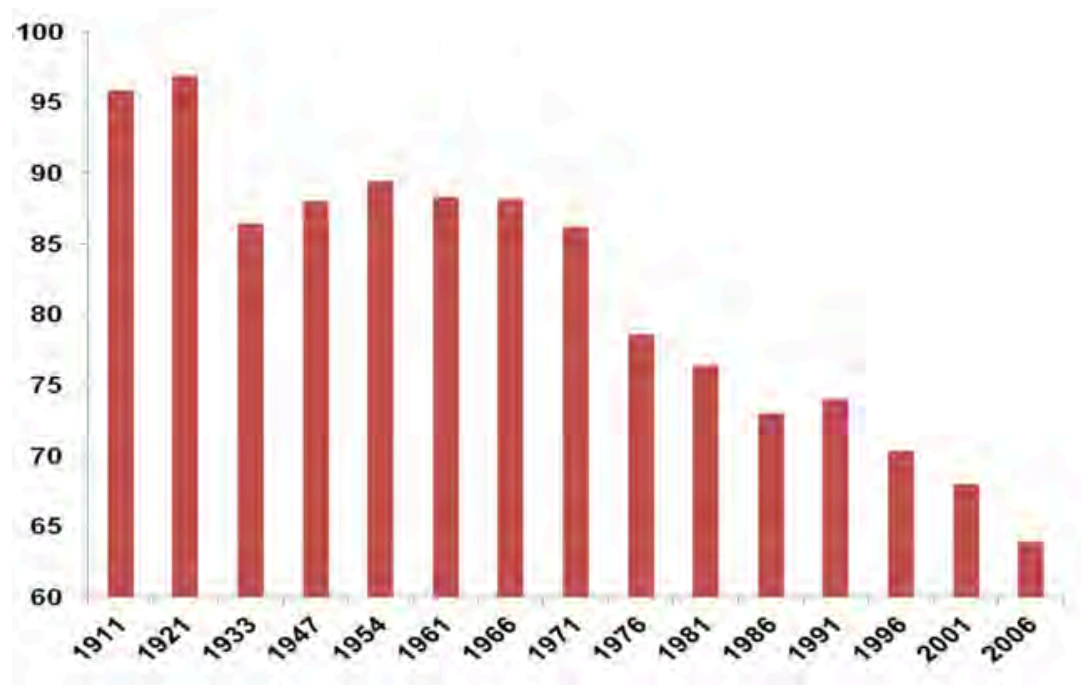

Figure 1: Christian affiliation, 1911 to 2006 (percentage of population)

Source: National Church Life Survey (NCLS 2010); ABS Yearbook of Statistics 2006, Cat No 1301.0.

While it may well once have been the case that "Sunday is the day of religious observance", this is only true of a minority of Australians today. Data compiled 
from various sources for the National Church Life Survey (NCLS 2010) indicate that while over 60 per cent of Australians consider themselves Christians, this has fallen from over 96 per cent in 1911 (see Figure 1).

According to that survey, the number attending church fell from 44 per cent in 1950 to 17 per cent in 2007 (see Figure 2). Clearly, Sunday is not a day of religious activity for the majority of Australians. According to the NCLS (2010), regular church attendance is concentrated among certain demographics. About half of church attenders are employed, 28 per cent are employed full-time, 14 per cent are employed part-time and 9 per cent are self-employed. Some 30 per cent are retired, reflecting the older age profiles of attenders. Around 15 per cent indicate that they are performing full-time home duties or family responsibilities and 9 per cent are students. Around 3 per cent are unemployed.

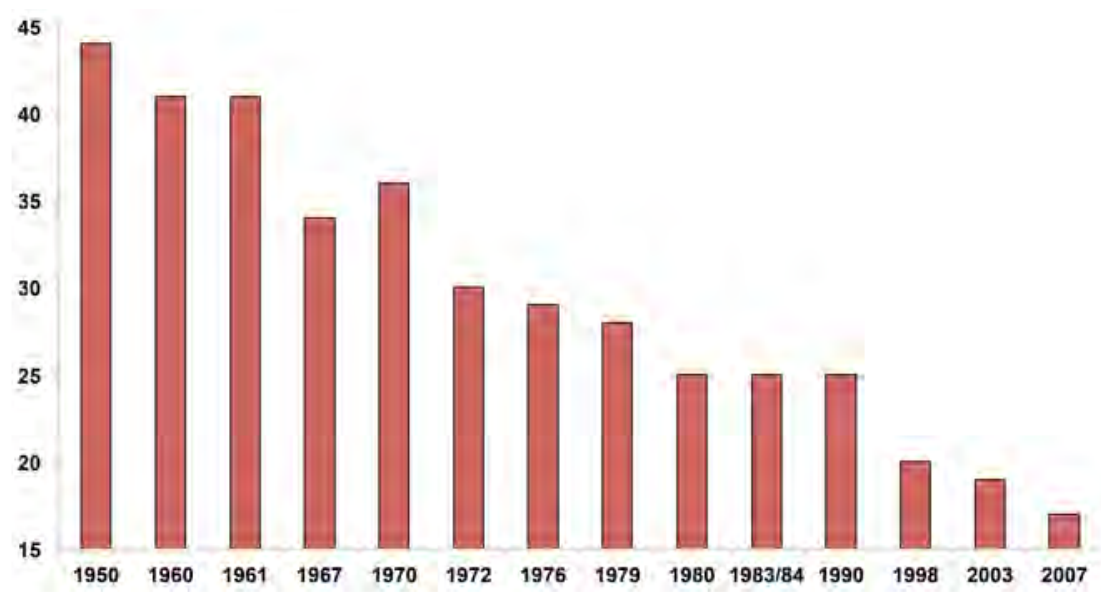

Figure 2: Regular church attenders, percentage of population

Source: National Church Life Survey (NCLS 2010, derived from 'various social surveys').

Among young people, although 15-19-year-olds represents 9 per cent of the population they make up less than 6 per cent of church attenders. For the 20-29 age group, the respective per centfigures were 17 and 9 per cent.

The Australian economy today is dominated by the service sector - part-time work, casual work, working women and flexibility are the norm for many. Also, the social mores which defined Australian society have to a large degree changed radically over time. Among the most relevant here are the growth in participation in education and the consequent supply of part-time and casual labour, participation in the workforce of women with children, and the use of 
leisure time for other activities, including church attendance and participation in sporting activities. Both of the latter account for a very small percentage of people's leisure time on weekends.

\section{The cafe, restaurant and catering services industry: A case study}

Penalty rates apply to many service industries but are particularly relevant to the cafe, restaurant and catering services industry, which receives particular attention in this paper.

According to the ABS (2008b) at the end of June 2007, the latest year for which detailed data are available, there were 15,423 businesses in Australia involved in the provision of cafe, restaurant and catering services. There are no reliable more recent estimates of the structure of the industry but it is unlikely to have changed significantly since. Collectively, these businesses employed 195,814 people. Total industry value added by these businesses was $\$ 5.7$ billion. During 2006-07, the operating profit before tax for these businesses was \$576.4 million and their operating profit margin was 4.2 per cent.

This does not include the industry's importance to to suppliers such as food wholesalers, farmers etc. or to complementary industries in, for instance, the tourism sector which benefit from amenable services at low prices from the industry.

In relation to costs, labour costs - which account for 36 per cent of the total - are the most significant expense. By comparison, labour costs for other industries make up about 20 per cent of the total on the average (ABS 2012d).

The cafe, restaurant and catering services industry is highly competitive and consists mainly of small businesses, with smaller cafes and restaurants accounting for around two-thirds (67.5 per cent) of the total. For the whole industry there are about 10,300 businesses (67 per cent) employing fewer than 10 people and 14,000 businesses (91 per cent) employing fewer than 20. These businesses employ about 100,000 people in total and generate over $\$ 13.7$ billion in income (ABS 2008b).

Cafe, restaurant and catering services are characterised by a large casual workforce which accounts for just over half of all employment. Permanent full-time employees account for under a quarter of all employment, while permanent part-time employees account for 15.5 per cent. Females account for just over half of all employment and most ( 57 per cent of female employment or 59,332 people) worked as casuals (ABS 2008b). The remaining categories of 
employment - working proprietors and partners of unincorporated businesses; and salaried directors of incorporated businesses - account for 5.7 per cent of total employment.

Over 40 per cent of all employees in the industry are under 24 years old, compared to less than 14 per cent for the economy as a whole. Clearly, the industry is a major source of employment for young people. The growth of part-time work for young people has also been a major factor in improving participation of youth in education.

Most employees in the industry are single. Women with children make up 22 per cent of the workforce in the industry and of these 57 per cent work parttime (ABS, Census of Poulation and Housing, 2006, unpublished). The industry has, together with retailing, the highest percentage of women with children working part-time.

The Restaurant Industry Award 2010 (AIRC 2010) sets out the minimum pay and conditions for workers in the industry. Specifically it provides for:

34.1 Penalty rates for work on weekends and public holidays

An employee working ordinary time hours on the following days will be paid the following percentage of the minimum wage in clause $20-$ Minimum wages for the relevant classification:

Table 2: Minimum wage rates for the relevant classification, cafes, restaurants and catering

\begin{tabular}{lllll}
\hline Type of employment & Monday to Friday & Saturday & Sunday & Public Holidays \\
\hline & $\%$ & $\%$ & $\%$ & $\%$ \\
Full-time and part-time & 100 & 125 & 150 & 250 \\
$\begin{array}{l}\text { Casual (inclusive of } 25 \% \\
\text { casual loading) }\end{array}$ & 125 & 150 & 175 & 250 \\
\hline
\end{tabular}

Source: (AIRC 2010).

In addition to these major features, there are a myriad of other conditions which employers must adhere to, such as: paying employees over 18 years of age the 21-year-old rate rather than the junior rate if they serve alcohol; penalties for working between 10pm and 7am; and a prohibition on lowest pay-grade workers from taking money from customers or showing them to their table! 


\section{The impact of penalty rates}

In assessing the impact of penalty rates on employment, it is first necessary to address the question of what determines employment in any industry (and the wage paid). The simple answer is, the demand and supply of labour. The matter is, however, complicated by institutional arrangements governing employment such as legally binding minimum wages and employment conditions (including penalty rates).

Businesses determine the demand for labour. The demand for labour is generally thought to depend on the wage rate or, more correctly, the costs of employing labour, which typically includes many other costs apart from the wage (see, for example, Hamermesh 1993; Lewis and Seltzer 1996; Lewis and MacDonald 2002). A firm's decisions about how much output to produce and how much labour to hire are made simultaneously. Firms hire extra labour when the value of the extra output produced is greater than the wage. Firms will only increase output if activities which were not previously profitable are made profitable. In the case of a restaurant, for example, if the size of the restaurant, number of cash registers, tables etc. remain fixed, each successive employee hired (or extra hour worked) will result in a lower increase in output than the one before. Businesses will employ more people (or increase hours of employment) as long as the extra revenue generated exceeds the extra cost of employing them. Therefore, extra output and extra employment requires a fall in labour costs and, conversely, a rise in labour costs will make otherwise profitable activities no longer profitable, so firms hire fewer people and produce less.

To get to grips with the effects of an imposed wage it is necessary to dig deeper into the operations of the labour market. In reality there is not a single labour market but rather very many labour markets each with their own supply and demand. An important characteristic of the multitude of labour markets is substitutability. Although it is common, particularly in the professions, to think of occupations being rigidly defined, in practice there is a great deal of substitutability of workers between and within industries and occupations.

In the case of a cafe/restaurant the potential for, or even necessity of, substitution is fairly obvious. Consider the following example. A cafe is staffed by a barista responsible mainly for the drinks; a cook who produces sandwiches and light meals; and various waiters/waitresses. The owner-manager does a whole range of tasks such as keeping the accounts and other paperwork, collecting supplies, hiring staff and doing virtually any of the jobs of other staff should the need arise. During peak times, or when colleagues are on breaks, the owner or other staff can take on different roles. One of the waitresses can only work between 9am and 3pm because she needs to drop off and pick up children from school. 
Mostly students are employed the rest of the time because they can fit work in around their classes. Students are particularly keen to work on weekends since it doesn't clash with study and they don't have the family commitments that some of their colleagues may have. For some of those with family commitments, however, weekend work can work to their advantage since a partner can look after children and avoid the child-care costs incurred when both partners are working during the week.

Most empirical studies of individual labour markets point to the high degree of substitutability, with respect to demand, between types of labour. There is also strong evidence that, given the degree of substitutability, the demand for labour in more narrowly defined labour markets is highly responsive to relative wages (Hamermesh 1993; Lewis 1985; Daly et al. 1999). Also, generally, the lower skilled the worker, the more responsive is demand to relative wages (Hamermesh 1993).

As is well known, the industry's elasticity of demand for labour depends on the elasticity of factor substitution, labour's share of total costs and the price elasticity of the demand for the industry's output. The precise formula (which sheds a lot of light on the relationship between wages and demand) for the longrun elasticity of demand can be shown (Hamermesh 1993) to be:

$\mathrm{e}=-(1-s) \sigma+s \eta ́$

where:

e is the elasticity of demand for hired labour (negative)

$\mathrm{s}$ is the proportion of hired labour costs in the total cost of production

$\sigma$ is the elasticity of substitution between hired labour and other inputs (positive)

$\eta$ is the elasticity of demand for output (negative).

In other words, what this formula says is that:

a. when wages rise this causes an increase in costs which firms must adjust to. The bigger the share of total costs which are hired labour costs then the larger the impact on firms. Firms will attempt to replace higher-cost labour with other inputs, such as family and owner's labour, and demand for hired labour will fall. Their ability to do this will depend on how easily hired labour can be replaced by other inputs, the elasticity of substitution, and how labour intensive the production process is (labour's share of total costs).

b. firms also attempt to pass on the increased costs to buyers of their products. If demand for these products is very price sensitive (high elasticity of demand for output), then even small cost increases cause large falls in demand for output 
and demand for labour. Output demand tends to be elastic where there is a high degree of competition and consumers regard goods and services as relative luxuries. If demand for these products is relatively insensitive to price (low elasticity of demand for output) then relatively small cost increases cause only small falls in demand for output and demand for hired labour. Low elasticity of demand is usually found where there is little competition and consumers regard goods and services as relative necessities, such as basic food and shelter. Nevertheless, whatever the size of the response, wage rises always cause a fall in demand for hired labour.

The above formula is for elasticity of labour demand in the long run, after capital has had time to adjust to any change rate. There is also a corresponding elasticity of labour demand in the short run, before capital has had any time to adjust (Hicks 1932).

$\mathrm{e}=\sigma \eta \dot{\eta} /(\sigma \mathrm{s}-[1-\mathrm{s}] \eta \dot{\eta})$

Using this framework the impact of wage changes in a particular industry can be predicted by making reasonable assumptions about the parameters, $s, \sigma$ and $\eta$. We saw above that in the cafe, restaurant and catering services industry hired labour accounts for a higher percentage of total costs (s) than for other industries, the degree of substitution between employees $(\sigma)$ is high and, since restaurant meals are generally thought to be luxury good (Hubbard et al. 2011), then $\eta$ is high. This suggests that a fall in wages in the industry would be expected to result in a significant increase in the demand for hired labour.

Providing precise estimates of the impact of wage changes on employment in an industry is difficult because there are few empirical studies available for Australia. However, making some reasonable assumptions, based on the following Australian and overseas evidence, one can provide some broad estimates.

The empirical work for Australia on the degree of substitution between different types of labour has largely arisen out of the debates regarding the appropriate rates for junior wages. In an early study for the Bureau of Labour Market Research, Lewis (1985) estimated the elasticities of substitution between young and adult workers by gender. He concluded that there was a very high degree of substitutability between different categories of labour and hence a high negative effect of wages on employment.

A well-known Australian study undertaken for the Productivity Commission (Daly et al. 1998) uses econometric analysis of a large cross-sectional data set (the Australian Workplace Industrial Relations Survey 1995) to isolate the influence of wages from the influence of other factors affecting youth employment. It found there is a significant substitution between youth and adult labour and 
hence a negative relationship between youth employment and youth wages. The best estimates suggest that a 1 per cent increase in youth wages would lead to a decrease in youth employment of 2-5 per cent in industries employing a relatively high proportion of youth.

Lewis and McLean (1999) carried out a simulation exercise on the effects of the 'adults at 18' proposal to abolish junior rates of pay for those over 18 proposed by the ACTU in the last junior wage case. Assuming elasticities of substitution of 1 between hired workers of different ages (a number far more conservative than those estimated by Lewis 1985 and Daly et al. 1998) they found that the effects of the proposal would have been to significantly reduce employment of 15, 16 and 17-year-olds.

There are few studies on the elasticity of demand for the output of the cafe, restaurant and catering services industry but they all conclude that it is large, which concurs with the general view among economists that 'eating out' is a luxury good. Published studies have estimated elasticities of demand for restaurant meals at -0.9 (Divisekera 2007), -1.46 (Eisenhauer and Principe 2009), -2.3 (Andersen et al. 1997) and between -1.49 and -3.8 (Jensen and de Boer 2006). The Divisekera (2007) study was for tourist demand, so is likely to be lower than for demand generally since tourists have fewer substitutes (fewer alternatives to eating out).

Studies (see, for instance, Cardoso et al. 2012) have considered the substitution of labour over times of the day or week as a result of differences in labour costs. For instance, firms may redirect production to those periods when overtime or penalty rates are not paid, in order to reduce labour costs. The degree of substitution has been found to be small (Cardoso et al.) for industries as a whole and the possibilities for reorganising production in the restaurant and catering industry would appear to be low. However, it is also possible that some 'demand-shifting' of output takes place to weekdays and away from weekend (public holiday) demand by consumers. For instance, if a restaurant is closed on Sunday, or charges higher prices, customers may shift their demand to a weekday. In this case the impact of penalty rates is to reallocate employment to weekdays. Unfortunately, there are little data on this to allow a judgement of its size.

On the basis of the above studies we can reasonably assume that $\sigma$, the elasticity of substitution for hired labour, is between 1 and 3; however, for completeness an elasticity of -0.5 is included in the analysis to account for the possibility that there is a lesser degree of substitution than suggested by the above studies; and $\eta$, the price elasticity of demand for cafe, restaurant and catering services, is between -1 and -3 ; and $s$ is 0.36 . 
Table 3 provides simulations of the elasticities of demand for labour based on these assumptions. Table 3 can be interpreted as follows. Assuming an elasticity of substitution of 2 and an elasticity of demand for industry output of - 1 then a fall in wage costs of 1 per cent would increase employment by 1.47 per cent in the short run and 1.64 per cent in the long run. Using the combinations of smallest and largest pairs of elasticities, respectively, lower and upper bounds for labour demand elasticities can be read from the table. For instance, given the reasonable range of assumptions, a 1 per cent fall in wage costs would increase employment by between 0.5 and 3 per cent (both the short run and the long run).

Estimates of the elasticity of demand for hired labour for any alternative pair of substitution and output elasticities can also be read from Table 3.

On the basis of the estimates of the elasticity of demand for hired labour, the impacts of penalty rates on demand by employers can be projected. For brevity, only the two extremes - the lowest possible and the highest possible elasticities of demand for hired labour - are shown in Table 4.

Table 3: Estimated wage elasticities of demand for labour, cafe, restaurant and catering services industry ${ }^{2,3}$

\begin{tabular}{|c|c|c|c|c|}
\hline \multicolumn{5}{|l|}{ Short Run } \\
\hline \multicolumn{3}{|l|}{$\begin{array}{l}\text { Elasticity of demand } \\
\text { for output } \eta\end{array}$} & \multicolumn{2}{|l|}{$\begin{array}{l}\text { Elasticity of } \\
\text { substitution } \sigma\end{array}$} \\
\hline & 0.5 & 1 & 2 & 3 \\
\hline-0.5 & -0.5 & -0.74 & -0.96 & -1.07 \\
\hline-1 & -0.61 & -1.00 & -1.47 & -1.74 \\
\hline-2 & -0.68 & -1.22 & -2.00 & -2.54 \\
\hline-3 & -0.71 & -1.32 & -2.27 & -3.00 \\
\hline \multicolumn{5}{|l|}{ Long Run } \\
\hline \multirow[t]{2}{*}{$\begin{array}{l}\text { Elasticity of demand } \\
\text { for output } \eta\end{array}$} & \multicolumn{4}{|c|}{$\begin{array}{l}\text { Elasticity of } \\
\text { substitution } \sigma\end{array}$} \\
\hline & 0.5 & 1 & 2 & 3 \\
\hline-0.5 & -0.5 & -0.82 & -1.46 & -2.1 \\
\hline-1 & -0.68 & -1.00 & -1.64 & -2.28 \\
\hline-2 & -1.04 & -1.36 & -2.00 & -2.64 \\
\hline-3 & -1.40 & -1.72 & -2.36 & -3.00 \\
\hline
\end{tabular}

Source: Author's estimates.

2 These elasticities of labour demand assume the firm is operating above the shutdown point, with a diminishing average product of labour. For a firm at the shutdown point the elasticity of labour demand to the wage is infinite. Shutdown can, and obviously does, happen as it does frequently on Sundays and public holidays.

3 Elasticities strictly refer to small changes in wages whereas increases due to (some) penalty rates are quite large. Assuming that $\sigma$ and $\eta$ are constant, the factor share, s, is endogenous in the following way: If $\sigma$ exceeds 1 , then the wage share falls with a rise in the wage rate, and the (long-run) elasticity becomes more negative, and the point elasticities in Table 3 are minimum bounds for the arc elasticity. If $\sigma$ is less than 1 , then the wage share rises with a rise in the wage rate, and the elasticity becomes less negative and the point elasticities become minimum bounds for the arc elasticities. If $\sigma$ equals 1 , then $\mathrm{s}$ is invariant to wage changes and the elasticity doesn't change. 
Table 4 can be read as follows. The first column of numbers is the percentage of ordinary time earnings under different penalty rates. So the requirement to pay 10 per cent extra between $10 \mathrm{pm}$ and midnight increases wages to 110 per cent of ordinary time. The other penalty rates can be read in the same way. The last two items probably require further explanation. "Junior 18 years" and "Junior 19 years" rows refer to the requirement that 18 and 19 year olds serving alcohol must be paid the adult rate. Therefore they receive 100 per cent of the adult ordinary time rate, which is 43 per cent more than their junior rate. Paying 19 year olds 100 per cent of the adult ordinary time rate represents an increased wage of 18 per cent of their junior rate.

Table 4: Changes in employment in the cafe, restaurant and catering services industry resulting from payments greater than standard hours

\begin{tabular}{lllll}
\hline & & & $\begin{array}{l}\text { Employment } \\
\text { percentage }\end{array}$ & $\begin{array}{l}\text { Change } \\
\text { (negative) }\end{array}$ \\
Type of employment & $\begin{array}{l}\text { Wage (\% of standard } \\
\text { adult rate) }\end{array}$ & $\begin{array}{l}\text { Wage increase } \\
\text { (\%) }\end{array}$ & $\begin{array}{l}\text { Lower estimate } \\
\text { Upper } \\
\text { estimate }\end{array}$ \\
\hline Ordinary time & 100 & - & - & - \\
10pm-midnight & 110 & 10 & 5.0 & 30 \\
Midnight-7am & 115 & 15 & 7.5 & 45 \\
Saturday & 125 & 25 & 12.5 & 75 \\
Sunday & 150 & 50 & 25 & $* *$ \\
Public Holidays & 250 & 150 & 75 & $* *$ \\
Junior 18 years & 100 & 43 & 21.5 & $* *$ \\
Junior 19 years & 100 & 18 & 19 & 55 \\
\hline
\end{tabular}

Notes: ${ }^{* *}$ denotes businesses would prefer not to employ anyone under these arrangements.

Source: Author's estimates.

The final two columns show the number of hours of labour demanded under the specified rates of pay relative to demand under standard hours of pay for all hours worked. For instance, in "Midnight-7 am" column the extra wage of 15 per cent reduces labour demand to between 92.5 per cent $(a$ fall of $7.5=15 \times 0.5$ ) and 55 per cent (a fall of $45=15 \times 3.0$ ) of what it would be if employees were paid the rate for standard hours. Penalty rates for Saturday work have the impact of reducing labour demand to between 87.5 per cent and 25 per cent of what it would be if employees were paid the rate for standard hours.

Some cells in the table contain ${ }^{* *}$, which means that given these wages and assumptions regarding elasticity of demand businesses will not want to hire any labour. Notice that under both the high and low scenarios this is the case for penalty rates on public holidays. Businesses will close on these days, make 
greater use of owner and family labour, or may choose to hire the absolute minimum amount of hired labour if they think it important to remain open as part of their business strategy. It is also possible that some businesses will come to some technically 'illegal' arrangements with employees outside of the award conditions.

To summarise, penalty rates for $10 \mathrm{pm}-$ midnight work are projected to have reduced demand for labour by between 5 and 30 per cent below what would be the case with no penalty rates. Penalty rates for midnight-7am work have reduced demand for labour by between 7.5 and 45 per cent below what would be the case with no penalty rates. Penalty rates for work on Saturdays are projected to have reduced demand for labour by between 12.5 and 75 per cent below what would be the case with no penalty rates. Penalty rates for work on Sunday are projected to have reduced demand for labour by between (under the low-estimate scenario) 75 per cent and 100 per cent (under the highestimate scenario). Penalty rates for public holidays are projected to have almost eliminated demand for hired labour.

What can be said is that the removal of industry-specific minimum rates would allow greater flexibility for owners to manage their businesses and allow wages to be determined by the market. Most economists believe that competitive markets, through the price mechanism, represent the best way of allocating resources (Hubbard et al. 2011). Businesses will maximise their profits by selling the goods and services consumers want, when they want, at the lowest prices. Production will be efficient because businesses will organise capital and labour in such a way as to reduce costs and maximise revenue in order to maximise their profits. Employment will be at a maximum because businesses are producing the highest output that people are willing to buy. In order to be able to hire workers, businesses must offer wages and conditions that employees are willing to accept. This is the basis for allowing businesses flexibility to manage and prices (including wages) to be determined by the market.

These results suggest that the imposition of penalty rates has had a significant negative effect on employment and turnover in the industry. Since profit margins are low, lower turnover would significantly reduce profits.

\section{Some indirect costs of penalty rates}

The above effects on labour demand are a result of direct costs imposed by regulations governing penalty rates. However, there are also costs relating to allocative inefficiency costs and compliance costs related to penalty rates. 
Allocative inefficiency costs arise because, in the presence of regulation, businesses will behave differently from the way they would without regulation (otherwise regulation would not be necessary), with subsequent impacts on the type, quantity and prices of goods and services. For instance, regulation might reduce competition which would increase prices, so that consumer welfare is reduced. Or restaurants having to meet industrial relations laws may have the effect of reducing the hours or days on which consumers can get a meal. In the longer term, regulation may well stifle innovation by restricting management prerogative on how to organise their business to reduce costs and provide better goods and services at lower prices.

Compliance costs fall into two general categories. The first relates to the costs of actually abiding by the regulation. These might involve hiring particular expertise (accountants or lawyers, for example), taking part in training or owners or staff having to devote time to educate themselves in what exactly is required under legislation and the costs of non-compliance. The second category of costs relates to demonstrating compliance with legislation. This mostly involves record keeping, which increasingly involves computer packages but is often referred to as paperwork or red tape. The boundary between actually complying with legislation and demonstrating compliance can be somewhat blurred. In the case of businesses in the cafe, restaurant and catering services industry, compliance costs arise from having to calculate penalty rates, to juggling staff to minimise wage costs, and demonstrating compliance with penalty rates. Clearly, the less regulation imposed upon these businesses the lower will be these costs.

\section{How strong is the hand of restaurant employees?}

The above analysis examines the impact on demand for labour of an increase or cut in wages of exactly the amount of the penalty rate and, conversely, the impact of a fall in wages exactly equal to the amount of the penalty rate abolished. However, the actual change in wages and, hence, the level of employment (hours worked) is determined by the interaction of supply and demand. Workers determine the supply of labour. They make decisions on where to work and the wage they are willing to accept on the basis of all the alternatives that are available. For instance, they will take into account what competitor employers are offering, and whether the job allows for flexibility to fit in with, say, study, parental duties or leisure time.

The greater the degree of competition for a person's labour, the less will an employer be able to have control over wages, since the worker will easily be able to supply their labour elsewhere (Norris et al. 2004). It would be expected that 
there is a great deal of competition for labour in the cafe, restaurant and catering services industry. The reduced labour demand arising from penalty rates reduces the availability of jobs, reducing competition on, say, Sundays, since many who want to work more hours cannot. Removing penalty rates would actually increase competition among employers for hired labour. Also, workers can find many jobs that demand similar skills and working conditions in the retail sector, hospitality, licensed clubs and the accommodation industries.

Several industries are competitors in the labour market for women with children with respect to a mix of part-time workers and the percentage of women. It can be concluded that there is a great deal of competition for female labour. This implies that there is little scope for the cafe, restaurant and catering services industry businesses to impose wages and conditions of employment which employees are not willing to voluntarily enter into.

One reason which could be put forward for the need for higher payments at certain times and days is the principle of 'compensating differentials' whereby additional payments have to be paid to employees in order to attract them to undertake unpleasant or dangerous work (Norris et al. 2004). In the context of penalty rates, the term 'unsocial hours' is often used to justify the need for compensating differentials (penalty rates) in order to attract employees during these hours. Certainly in the days when a typical worker worked full-time, five days per week or more, this may have been true but this is hardly true of the cafe, restaurant and catering industry. The final test of whether employees need to be compensated (receive higher pay) for unsocial hours is whether businesses can attract people to work these hours at the standard rate of pay. If they cannot then clearly the standard rate of pay would be too low and businesses would need to offer higher rates to attract people. The market would determine the appropriate penalty.

However, in a labour market such as that characterised by the cafe, restaurant and catering services industry, full-time work is the exception rather than the rule. Also, for students, the hours typically characterised as unsocial are actually the hours when they are free from obligations to attend their school, college or university. The industry is characterised by great flexibility in employment, which implies a great deal of scope for employees to choose the hours and days they want to supply their labour. 


\section{Who would benefit from removing penalty rates?}

Those who are lucky enough to be employed benefit most from the current arrangements and might be worse off without penalty rates, although we cannot be sure because these people may well want more hours of work which they cannot currently get. The question arises as to who would benefit from changes to penalty rates.

Owners of cafe, restaurant and catering services businesses would benefit but not necessarily greatly. This is because the industry is very competitive. In a competitive industry most cost savings are eventually passed on to consumers in lower prices as output expands from both existing firms and by new firms entering the industry (Hubbard et al. 2012). Profit margins would be expected to fall to the rate they were before the fall in labour costs. The volume of profit per business will increase as turnover is increased. A greater ability of managers to organise the business in the most efficient way would be expected to improve the productivity of the sector.

Suppliers (and their employees) to businesses in the industry, such as food wholesalers, farmers, and commercial property renters, would benefit as output of the industry rises, increasing the demand for inputs. Complementary industries, such as those in tourism, for example, would benefit from customers having a greater range of choice and lower prices. Australia would be a more attractive destination for overseas tourists.

There would unambiguously be more employment in the industry as turnover increased. There would be greater choice of shifts available. There would be more employment opportunities for the unemployed, with the potential for providing a stepping-stone into further employment.

Some employees, although their wage rate may fall, may even receive higher totalearnings without penalty rates since the potential to work a greater number of hours will increase.

The biggest beneficiaries from removing penalty rates would be consumers. They would pay lower prices, eat out more and at times which better suit their lifestyle.

The removal of penalty rates would make the economy more efficient and productive as distortions in the allocation of resources would be reduced. 


\section{The Fair Work Commission's Restaurant Award}

The arguments presented in this paper formed the basis for the restaurant industry case in the Fair Work Commission's two-yearly review of the Restaurant Industry Award 2010 (Restaurant Award). In her judgement of 10 October 2013, Deputy President Gooley rejected a large range of proposals to vary the award, including proposals to reduce pay rates for small businesses, abolish weekend penalty rates and modify the classification structure of the award (FWC 2013).

However, in response to an appeal by the Restaurant and Catering Association of Victoria (RACV) the majority of the Full Bench (not without strong opposition from the minority) on the 14 May 2014 came to a monumental, if somewhat confusing, judgement (FWC 2014):

The RCAV's case that the reduction in the Sunday penalty rate from $50 \%$ to $25 \%$ would have significant benefits for employment and business turnover was not made out.

but

It is accepted however that Sunday penalty rates may have a limited effect on employment, particularly in relation to owner-operators working on Sundays in preference to engaging staff for additional hours.

and

... for transient and lower-skilled casual employees working mainly on weekends, who are primarily younger workers, the superimposition of the casual loading of $25 \%$ in addition to the $50 \%$ penalty tends to overcompensate them for working on Sundays and is more than is required to attract them for work on that day.

In summary, the penalty rate for casual low-skilled workers at the Introductory level, Level 1 and Level 2 (basic kitchen and waiting staff) on Sundays has been reduced from 50 per cent to 25 per cent. However, for workers at Level 3 to Level 6 (cooks etc.) the award is unchanged, as it is for those employed on a permanent basis who work on Sundays.

Also, somewhat intriguingly, the Full Bench (FWC 2014) found that:

The Restaurant Award shall be varied, effective from 1 July 2014, to allow employees classified as Food and Beverage Attendants Grade 1 to receive money from customers, and employees classified as Food and 
Beverage Attendants Grade 2 to take reservations and greet and seat guests, subject to the requirement that no existing employee should have his or her classification reduced as a result of this variation.

While the above changes may seem to be relatively minor and there is still a reluctance to admit that employment and wages are related, the decision by the Full Bench has been greeted by commentators, industry associations and businesses as a monumental decision. Hopefully the FWC's (partial) acceptance that (some) penalty rates are an unnecessary impediment to businesses has opened the door to further labour market reform.

\section{References}

Anderson, Patrick L., McLellan, Richard D., Overton, Joseph P. and Wolfram, Gary L. 1997, "Price Elasticity of Demand", Makinac Center for Public Policy, 13 November, http://www.mackinac.org/article.aspx?ID=1247.

Australian Bureau of Statistics 2008a, Time Use on Recreation and Leisure Activities, Australia, Cat No 4173.0.

— 2008b, Cafe, Restaurant and Catering Services, Cat No 8655.0.

— 2010, Employee Earnings, Benefits and Trade Union Membership, Cat No 6310.0 .

_ 2012a, Labour Force, Australia, Spreadsheets, Cat. No. 6202.0.55.001.

_2012b, Retail Trade, Australia, Cat No 8501.1.

— 2012c, Business Indicators, Australia, Cat No 5676.0.

- 2012d, Australian Industry, Cat No 8155.0.

Australian Industrial Relation Commission (AIRC) 2010, Restaurant Industry Award 2010, AIRC, Melbourne.

Cardoso, R.A., Hamermesh, D.S. and Varejão, J. 2012, “The Timing of Labor Demand", Annals of Economics and Statistics, Number 105/106, January/ June.

Colmar Brunton Social Research 2008, "Accommodation, Cafes and Restaurants Industry Profile - Quantative Analysis", in Accommodation, Cafes and Restaurants Industry Profile - Interim Electronic Report, Research Report No 1/09, AFPC, Melbourne. 
Commonwealth Court of Conciliation and Arbitration (CCCA) 1919, Federated Gas Employees Industrial Union v Geelong Gas Company and Others (1919), AR 13, pp 468-69.

Commonwealth Court of Conciliation and Arbitration (CCCA) 1947, The Metal Trades Award re Rheem Manufacturing - Judgement re Rates of Pay for Work Performed on Saturdays and Sundays, AR 609, pp 609-23.

Corliss, M. and Lewis, P. 2012, “Tradespersons Earnings Over the Business Cycle", Economic Papers 31(2): 160-172.

Daly, A., Nguyen-Hong, D., Eldridge, D., Gabbitas, O. and McCalman, P. 1998, "Youth Wages and Employment", Productivity Commission Staff Research Paper, Ausinfo, Canberra, October.

D'Amore, A. 2005, Speech to the New South Wales Parliament, Hansard, 1 March 2005, pp. 14324-25.

Divisekera, S. 2006, Modelling and Estimation of Tourism Elasticities, CRC for Sustainable Tourism Technical report.

Eisenhauer, J.G. and Principe, K.E. 2009, "Price Knowledge and Elasticity", Journal of Empirical Generalisations in Marketing Science 12(2).

Fair Work Commission (FWC) 2013, Modern Awards Review 2012 Restaurant Industry Award 2010, www.fwc.gov.au/documents/documents/ summaries/2013fwc7840_summary.htm.

FairWork Commission(FWC)2014, Restaurantand Catering Associationof Victoria, www.fwc.gov.au/documents/documents/summaries/2014fwcfb1996_ summary.htm.

Garnett, A. and Lewis, P. 2010, "The Economy", in Aulich, C. and Evans, M. (eds), The Rudd Government, ANU E Press, Canberra.

Hamermesh, D.S. 1993, Labour Demand, Princeton University Press, New Jersey.

Hicks, J.R. 1932 The Theory of Wages, London: Macmillan.

Hubbard, R., Garnett, A., Lewis, P. and O'Brien, A. 2011, Microeconomics, 2nd edition, Pearson, Sydney.

Jensen, B.S. and de Boer, P. 2006, "Long-Run Patterns of Demand: The Expenditure System of the CDES Indirect Utility Function - Theory and Applications", DEGIT conference paper c011-056.

Lewis, P. 1985, "Substitution Between Young and Adult Workers", Australian Economic Papers 24(44): 115-126. 
— 2006, Minimum Wages and Employment, Australian Fair Pay Commission, Research Report 1/06.

— 2008, The Labour Market, Skills Demand and Skills Formation, Research Report No 6, The Academy of Social Sciences in Australia, Canberra.

Lewis, P., Garnett, A., Hawtrey, K. and Treadgold, M. 2010, The Australian Economy: Your Guide, Pearson Australia, Sydney.

Lewis, P. and McDonald, G. 2002, "The Elasticity of Demand for Labour in Australia", Economic Record 78(240): 18-30.

Lewis, P. and Mclean, B. 1998, "The Youth Labour Market in Australia", Australian Journal of Labour Economics 2(2): 157-72.

— 1999, "The Adult at 18 Alternative", Australian Bulletin of Labour 25(3): 275-80.

Lewis, P. and Seltzer, A. 1996, "Labour Demand" in Norris, W.K. and Wooden, M. The Changing Australian Labour Market, AGPS, Canberra.

Lowe, P. 2012, "The Euro Crisis and the Financial System", presentation by the Deputy Governor of the Reserve Bank of Australia, The Economist Bellwether Series, 12 July, Sydney.

National Church Life Survey (NCLS) 2010, Why Innovation is Needed in Church Life, NCLS Research Fact Sheet, www.ncls.org.au/default.aspx? sitemapid $=6516$.

New South Wales Arbitration Commission (NSW) 1972, Shift Workers Case AR 72: $647-51$.

Norris, K., Giles, M. and Kelly, R. 2004, Economics of Australian Labour Markets, Pearson Australia, Sydney.

Organisation for Economic Cooperation and Development (OECD) 2005, Employment Outlook 2005, Paris.

Seltzer, A. 1997, "An Evaluation of the International Evidence on the Employment Effects of Minimum Wage Legislation", Australian Economic Review 30(2): 208-14. 
This text taken from Agenda: A Journal of Policy Analysis and Reform Volume 21, Number 1, 2014, published November 2014 by ANU Press, The Australian National University, Canberra, Australia. 